\title{
A Proposed ESP On-Line Course for Developing Reading Comprehension Skills of Commerce University Students
}

\author{
Lina Ahmed Nabil Mahmoud Seif
}

\begin{abstract}
The present study aimed at investigating the effect of using an ESP on-line course on developing reading comprehension skills. The target reading comprehension sub- skills were: Predicting, Making relationship, Identifying information, and Word Recognition. The researcher used the quasi-experimental design. The participants in the study included one experimental group $(\mathrm{N}=30)$ freshman students at the Faculty of Commerce, Mansoura University. The instruments used were 'Needs analysis questionnaire, reading comprehension skills questionnaire and a pre-post reading comprehension test'. Validity and reliability were established before administering the pre-post reading comprehension test. The study was conducted during the first semester of the academic year 2017/2018. Results showed that there was a statistically significant difference between the pre and post administrations of the reading comprehension test in favor of the posttest. Results indicated that an ESP program has an effective impact on developing reading comprehension skills for freshman students at the Faculty of Commerce, Mansoura University.
\end{abstract}

Key words: ESP, E-learning, On-line course, Reading comprehension skills.

\section{Introduction}

Instead of a one-size-fits-all form of English, ESP concentrates on subject-specificity. El-sheikh (1986), a pioneer researcher in the field of ESP studies in Egypt, has argued that ESP aims to provide course-specific English language requirements for professionals who often require specific content-based vocabulary such as engineer, scientist, accountant, etc. ESP is likely designed for andragogy - to empower students to pursue their own aspirations. Conducting in-depth needs analysis is an essential first step for developing an ESP course.
Needs analysis serves an ESP course in setting the goals and preparing ESP materials and activities. Thus, ESP is learnerscentered, needs-oriented, and jobrelated approach which focuses on many aspects of structure and use of language. Therefore, learners focus on one or more language skill that is needed for specific purposes.

To read and comprehend English texts in a specific field, we need to study ESP. There is an agreement that reading is an essential skill for the students in ESP to understand the authentic text in their own field. Authentic materials refer 
to "real-life texts" and they have positive effects on the reading comprehension for advanced students. Murcia (1991) stated that academic reading in ESP courses assert on two elements: "reading to learn" - such as the activities that focus on understanding the content- and "learning by doing" - where activities focus on the use of the ideas or knowledge in any area

Integrating technology in education facilitates teaching ESP. Information technology like elearning and online learning are one of an open platform for multimedia leaning sources in ESP depending on the internet application such as websites and online programs. Online programs increase the availability of educational opportunities for students. In ESP, it fosters autonomous learning and self- learning, and establishes highly interactive learning environment using authentic materials, e-learning and online learning. For this reason, using websites and online programs positively affects developing reading comprehension skills such as scanning, skimming, paraphrasing, summarizing, organizing, analyzing and problem- solving skill.

\section{Review of literature}

\section{Reading comprehension skills in ESP}

Throughout history, there are many definitions of "reading". Urquhart and Weir (1998) defined reading as the method of receiving and interpreting information that encoded in language through the medium of print. Chia (2001) as cited in Nada 2005) viewed reading as an interaction process between readers' prior information and the knowledge that encoded in the text. Carrel (1988) claimed that reading skill is the most significant skill among the four skills of English as a second or a foreign language for many students. According to Afflerbach, Person, and Paris (2008), reading skills are automatic actions that lead to the decoding and comprehending with speed efficiency and fluency and happen without awareness of the component. Dictionary (2001) mentioned some reading skills as skimming, scanning, pronoun reference, identifying basic words, using cognates and summarizing. Snow and Sweet (2003) defined reading comprehension as the process of constructing meaning via interaction and participation with written language.

Day and Krzanowski (2011) reported that ESP includes teaching particular skills and language that are needed by certain learners for specific purposes. For ESP learners, reading is more important because learners' proficiency or deficiency in this skill would have the major effect on learners' future academic and professional progress. Johnsons (1998) indicated that in ESP teaching the focus has been on the skill of reading, for the practical purposes in various study contexts in the whole world. In addition, the reader's understanding will be enhanced with better understanding of ESP texts. Hutchinson and Waters (1987) 
illustrated that in the initial stage of ESP's development, the analysis had been the basic form of the language in the form of register analysis, that is, the study at the sentence level of the use of the language in different communicative settings such as airplane mechanics, nurses, and bank tellers.

According to Harmer (2001), the authenticity of reading materials presents serious difficulty to students, because there is foreign learners' consciousness lack in encountering non-simplified content. Grabbe (1991) noted that ESP reader is based on definite content and organized plan rather than the use of language knowledge in the text. Celece-Murcia (1991) stated that academic reading in ESP courses should assert on two elements: "reading to learn" such as the activities that focus on understanding the content and "learning by doing" where activities focus on the use of the ideas or knowledge in any area. Swales (1990) mentioned that in genre analysis, ESP course can be taught to meet certain professional needs such as how to recognize (as a reader) and mimic (as writers) the so-called schematic structure process. Hajjaj(1989) argues that reading in ESP should be based on authentic texts that the students need it in their specialization. According to Marshal and Gilmour (1993), ESP practitioner should not teach various scientific and technical words but teach the meaning of contexts and structural relations.
Torregrosa and Sánchez-Reyes (2011) noted that the use of authentic materials is an important tool in ESP classes to stimulate learners to learn the target language that they need. Bruce (2011) noted that the major element of reading instruction is the development of sub -skills related to eliciting different kinds of information from texts, such as skimming and scanning the text. Pritchard and Nasr (2004) clarified the successful results of reading comprehension skill in ESP is training students in using contextual clues and authentic texts in their field. Basturkmen(2006) asserted that reading comprehension skill in ESP make ESP readers understand the complicated invisible discourse and visible discourse they encounter as readers.

\section{Integration of Technology in ESP Reading Instruction}

Arnó-Macía (2012) and Golonka (2014) illustrated that the relationship between information technology (IT) and ESP is still under an influence of the evolution of computer-assisted language learning (CALL) with the developments in applied linguistics and language teaching. Egbert (2005) has also concentrated on the necessity of using computers to support reading and writing skills as well as grammar involved in those skills in saying that: "Students can check exercises after they are done, move gradually from easier to more difficult exercises according to their abilities and levels. When students fail to answer correctly or perform activities, the computer 
can simulate, drill or explain the phenomenon." As Harmer (2003) confirmed that there are many and varied sources offered and presented on the screen and with the development of the web, reading a computer screen has become a more realistic assignment. Tsai (2006) investigated the effects of Web Quest use on reading vocabulary acquisition and reading performance of Taiwanese EFL university students. Results indicated that the use of the WebQuest module produced a significant difference in students' story reading comprehension and vocabulary acquisition. Marco (2002) illustrated the advantages of Web quests are: enhancing cooperative learning, attracting students in performing real world tasks, choosing authentic online materials, stimulating learner motivation, developing reading skills such as scanning, skimming, paraphrasing, summarizing, organizing, and solving problems. The study of Salama (2016) conducted that Electronic Program based on ESP has significant effect on developing Home Economics Student's Oral Communication Skills"

According to bouklikha (2016), the positive results seem to confirm implementing web-based activities in ESP reading instruction, because students are interested to learn English and teachers can provide them with variety resources for acquiring knowledge by using e-mail as means of communication. It also assists the students to overcome their difficulties in performing their reading activities by helping each other and gaining profit from the teacher's help when clarifying ambiguities and misunderstanding. The use of webretrieved materials in this course is the method for encouraging students' autonomy, increasing motivation and escaping from monotony and routine. Omar (2015) study aimed to investigate the effect of using computer-based concept map on a group of pre-medical Saudi students' reading comprehension. The findings indicate that using computergenerated concept maps as a learning strategy has a positive impact on students' reading comprehension level. Consequently, the present study aimed at investigating the effect of using a proposed ESP on-line course on developing reading comprehension skills.

\section{Pilot Study:}

Students at faculty of Commerce lack necessary reading comprehension skills, so the researcher conducted to a reading comprehension test on 30 freshman students at faculty of Commerce, Mansoura University to assess the actual level of their reading comprehension skills. The participants read ESP text relevant to their field. Then, they answered ten questions measuring some reading sub-skills. The following table shows the mean scores, standard Deviation, and percentage of reading section in the English language test: 
Results of the pilot study:

Table1: Results of the pilot study

\begin{tabular}{|l|c|c|c|c|c|}
\hline Reading sub - kills & Max. score & Min. score & Mean & SD & $\%$ \\
\hline skimming a text for the gist & 5 & 1 & 2.3 & 1.8 & $26 \%$ \\
\hline $\begin{array}{l}\text { scanning a text for specific } \\
\text { of information }\end{array}$ & 6 & 2 & 1.6 & 2.7 & $8 \%$ \\
\hline $\begin{array}{l}\text { Identifying the meaning of } \\
\text { difficult words }\end{array}$ & 5 & 1 & 1.5 & 1.4 & $20 \%$ \\
\hline Inferencing & 6 & 1 & 2.5 & 2.7 & $27 \%$ \\
\hline Total & 22 & 5 & 7.9 & 8.6 & 20.25 \\
\hline
\end{tabular}

Results in the table (1) show that the total percentage of students' score is very low $(20.25 \%)$. This means that those students need to develop their reading comprehension skills in English for specific purposes.

\section{Statement of the problem:}

Based on the literature review and the results of the pilot study, the problem can be stated as follows:

Teaching reading comprehension skills for freshman students at faculty of Commerce with its traditional practice does not equip students with the necessary skills to master this component of English language. This traditional practice relies mostly on introducing the new vocabulary, reading silently and then answering some comprehension questions mostly in Arabic, which does not help much, seemingly, to develop students' reading sub-skills. Students have weakness in understanding the text, the meaning of commercial terms and pronouncing difficult words correctly.

Consequently, the use of a proposed ESP on Line course may assist freshman students at faculty of Commerce in developing their reading comprehension skills to qualify them to have a good job in their career. Moreover, the present study aims at investigating the effect of using a proposed ESP online course on enhancing reading comprehension skills.

\section{Questions of the study:}

The problem of the study will be explored through answering the following main question:

To what extent does an online ESP course contribute to enhancing reading comprehension skills of freshman students at faculty of Commerce?

This main question leads to the following sub-questions:

1- What are the features of an ESP online course for developing reading comprehension skills for freshman students at faculty of commerce?

2- What are the necessary reading sub skills for ESP purpose that should be mastered by freshman students at faulty of Commerce by the end of the course?

3- What are the effectiveness of the proposed ESP online course in developing reading 
comprehension skills of those students?

\section{Purposes of the study:}

The present study aimed at:

1-Developing the most necessary ESP reading comprehension skills for freshman students at faculty of Commerce.

2- Identifying the features of an online ESP course for freshman students at faculty of Commerce.

3- Measuring the effectiveness of using an on line ESP course for developing reading comprehension skills for freshman students at faculty of Commerce.

\section{Significance of the study:}

The current study could contribute to:

1- Proposing a framework of an ESP online course for developing ESP reading comprehension skills in the undergraduate stage to be implemented.

2- Measuring the effectiveness of using ESP online course for improving reading comprehension skills.

3- Directing the attention of ESP teachers and curriculum designers to the significant use of technology for developing language skills.

4- Giving more consideration to the use of authentic commercial texts as an effective tool in enhancing reading comprehension skills.
5- Emphasizing the importance of using ESP online course to help students to take charge of their own learning to master English language skills.

\section{Delimitation of the study:}

The study will proceed within the following delimitations:

1- A sample of freshman students at faculty of Commerce, Mansoura University.

2- ESP online course focused on developing reading comprehension skills.

\section{Hypothesis of the study:}

This study attempted to verify the following hypothesis:

There is a statistically significant difference between the mean score of students in the experimental group on the pre and post-administration of the reading comprehension test in favor of the post -test.

\section{Methodology of the study:}

Methodology of the current study includes the participants, instruments, design, and procedures that followed to carry out the study.

\section{Participants:}

The participants were thirty students enrolled in the first-year at faculty of Commerce, Mansoura University. The researcher selected the students from commerce faculty because the students study English course entitled "English commercial studies". Moreover, the students need to read and understand the course and the commercial terminology in it. Therefore, the researcher attempted to 
design an appropriate program for qualifying students to read and understand their courses.

\section{Instruments:}

The following instruments were designed in the current study:

1-Need analysis questionnaire to identify students' needs and to determine the necessary ESP reading comprehension skills that should be mastered by the participants.

2- A pre-post ESP reading comprehension test to assess the reading comprehension skills of the participants.

\section{Aim of the study:}

The study aimed at developing reading comprehension skills for 30 first- year students at faculty of Commerce in Mansoura University.

\section{Significance of the study:}

The study is helpful for:

(1) Students: It provides on-line program that meets students' needs in academic contexts to fulfill students' academic achievement and to be suitable for English language demands of students' future career. Moreover, the study helps students to develop reading comprehension skills and have an active role in reading authentic materials in their field by themselves. Therefore, the study achieves some features for students as self-directed, self- passed and self-study.

(2) Faculty members: It provides on-line program for faculty members who teach English Commercial studies to use it in teaching the syllabus.

(3) Researchers: It attracts the researchers to concentrate on specializations and some basic elements of ESP studies.

(4) Designers of ESP courses: It attracts the attention of ESP course designers to focus on students' needs.

Variables of the study:

1- The independent variable is the proposed ESP online program.

2- The dependent variable is students' reading comprehension skills.

Approach of the study:

The researcher used the descriptive and analytical approach to analyze students' needs. In addition, the researcher used the quasiexperimental approach to identify the effectiveness of the proposed ESP program.

\section{Procedures:}

1- Reviewing related literature and studies to identify the existing trends of E-learning to develop reading comprehension skills in English.

2- Selecting the participants of the study who are freshman students at Faculty of Commerce, Mansoura University.

3- Preparing the tools of the study and submitting them to a group of commerce students for validation. 
4- Presenting the form of need analysis questionnaire for students to determine the most important reading comprehension skills necessary for those students.

5- Preparing pre-reading comprehension test in its initial form for a group of commerce students to determine its validity.

6- Preparing an ESP program (cloudscorm) that is a learning platform based on reading comprehension skills.

7- Implementing the proposed course of reading comprehension skills to commerce students.

8- Implementing post- reading comprehension skills test.

9- Applying appropriate static procedures to obtain the results.
10- Collecting data and analyzing them statistically using the suitable statistical methods.

11- Discussing results, drawing conclusions and presenting recommendations.

Results and discussion of the study:

The main hypothesis of the study was:

"There is a statistically significant difference between the mean score of students in the experimental group on the pre- and post-administration of the reading comprehension test in favor of the post-test."'

In order to verify this hypothesis; a "t" value of the difference between the mean score of students in the experimental group on the pre- and post-administration of the reading comprehension skills test was calculated. Results are shown in table (2).

Table (2): Results of t-test of the experimental group on the pre-postadministration of the reading comprehension test $(\mathrm{N}=30)$

\begin{tabular}{|c|c|c|c|c|c|c|c|}
\hline Skills & $\begin{array}{c}\text { Measure- } \\
\text { ment }\end{array}$ & $\mathbf{N}$ & Mean & SD & $\mathbf{T}$ & $\begin{array}{c}\text { D. f } \\
(\mathbf{n}-1)\end{array}$ & $\begin{array}{l}\text { Sig. (2- } \\
\text { tailed) }\end{array}$ \\
\hline \multirow[t]{2}{*}{ Predicting } & Pre & 30 & 2.9333 & 1.38796 & \multirow[t]{2}{*}{7.5} & \multirow[t]{10}{*}{29} & \multirow{10}{*}{$\begin{array}{l}\text { Significant } \\
\text { at } 0.05\end{array}$} \\
\hline & Post & 30 & 4.8667 & .34575 & & & \\
\hline \multirow{2}{*}{$\begin{array}{c}\text { Making } \\
\text { relationships }\end{array}$} & Pre & 30 & 2.4333 & 1.45468 & \multirow[t]{2}{*}{7.14} & & \\
\hline & Post & 30 & 4.3000 & .74971 & & & \\
\hline \multirow{2}{*}{$\begin{array}{l}\text { Identifying } \\
\text { information }\end{array}$} & Pre & 30 & 1.1333 & .89955 & \multirow[t]{2}{*}{16.2} & & \\
\hline & Post & 30 & 4.1333 & .89955 & & & \\
\hline \multirow{2}{*}{$\begin{array}{c}\text { Word } \\
\text { recognition }\end{array}$} & Pre & 30 & 1.7667 & .89763 & \multirow[t]{2}{*}{8.4} & & \\
\hline & Post & 30 & 3.8000 & .99655 & & & \\
\hline \multirow[t]{2}{*}{ Total } & Pre & 30 & 8.2667 & 2.89986 & \multirow[t]{2}{*}{18.7} & & \\
\hline & Post & 30 & 17.1000 & 1.39827 & & & \\
\hline
\end{tabular}

Results in the above table (2) show that the estimated $t$-value is indicates that there is statistically significant at 0.05 level. This significant differences between the mean scores of the pre-post- 
administrations of the reading comprehension test in the four skills and in the total score. These significant differences are in favor of the post-test.

The low scores of pre-test of reading comprehension skills revealed that students lack the reading comprehension skills. This led to the misunderstanding of the whole text and inability of answering the questions. Exposing students to ESP online course helps freshman students to predict information, make relationship, identify information and recognize the words. All these skills enabled students to develop their reading comprehension

Table(2) shows that the value of the mean score of the post-test is
(17.1000) that is higher than the mean score of the pre-test that is (8.2667) as the $\mathrm{T}-$ value is (18.7). This reveals that there is an increase in the scores of the experimental group students on the post -test than the scores of pre-test that are related to reading comprehension skills. This means that the proposed ESP program was effective in developing the targeted reading comprehension skills.

\section{The square of Eta ( $\eta 2)$ :}

To measure the extent to which the proposed program was effective in developing the targeted reading comprehension skills. Table (3) shows the effect size of the proposed treatment was estimated. To measure the program effect size, the square of eta $(\eta 2)$ was estimated.

Table (3) : Value of ( 2 2) and Levels of Effect Size

\begin{tabular}{|c|c|c|c|c|c|}
\hline $\begin{array}{l}\text { Independent } \\
\text { variable }\end{array}$ & $\begin{array}{l}\text { Skills of the dependent } \\
\text { variable }\end{array}$ & $\mathrm{T}$ & $\begin{array}{l}\text { D. } \mathrm{f} \\
(\mathrm{n}-1)\end{array}$ & $\begin{array}{l}\text { Value of Eta } \\
\text {-square }(\eta 2)\end{array}$ & $\begin{array}{l}\text { Level of } \\
\text { Effect Size }\end{array}$ \\
\hline \multirow{5}{*}{$\begin{array}{c}\text { The proposed } \\
\text { ESP } \\
\text { program }\end{array}$} & Predicting skills & 7.5 & \multirow[t]{5}{*}{29} & 0.66 & \multirow[t]{5}{*}{ High } \\
\hline & $\begin{array}{l}\text { Making relationships } \\
\text { skills }\end{array}$ & 7.14 & & 0.64 & \\
\hline & $\begin{array}{c}\text { Identifying Information } \\
\text { skills }\end{array}$ & 16.2 & & 0.90 & \\
\hline & $\begin{array}{l}\text { Word Recognition } \\
\text { Skills }\end{array}$ & 8.4 & & 0.71 & \\
\hline & Total score & 18.7 & & 0.92 & \\
\hline
\end{tabular}

The main goal of the present study was to investigate the effectiveness of using ESP online course on developing reading comprehension skills for freshman students at faculty of Commerce, Mansoura University. The abovementioned results revealed that using ESP online course was highly effective. Such results indicated that there are significant differences between the mean score of the experimental group on the pre- and post-administration of reading comprehension test on the experimental group is shown in table (3). This confirms the effectiveness of using ESP on line course for developing reading comprehension skills.

In addition, this appears in the students' performance and their 
answers of the questions. The comparison between students' performance at the beginning, middle and end of treatment implementation reveals their progression and development. At the very beginning, students have difficulty in their own skills of predicting the information, making relationship, recognizing the commercial words and identifying the information during reading the text. Thus, browsing the internet and applying program on the website help students to overcome the challenges they faced.

Cloudscorm was used as a learning platform because it is simple to use and powerful to be adopted by instructors. The tools provided by Cloudscorm raised the interaction between instructors and students. The videos taken from the Youtube provided authentic material that motivate students and helped them develop their skills.

Results of this study are consistent with those of Elhefnawi's study (2017) that investigated the effectiveness of an ESP content-based program in Developing some English language skills for Higher institutes of social work students, and the study of Bouklikha(2016) that handled the practice of reading skill in an ESP context using web-retrieved material and highlighted that a higher level of reading comprehension can be achieved through using numerous strategies and implementing webbased materials.

Results of the current study resemble the findings of other studies like El-shater (2015) that investigated the effectiveness of an ESP program in developing some language skills among Commerce faculty. The program is designed for providing the students with feedback and for improving the four skills, the study of Romero (2017) that focused on developing Reading Comprehension Skills in an ESP Course through a Theme and Task Based Learning", and the study of El-Dahrawy(2016) that handled the Implementation of a Computer -based Virtual Environment for developing the Reading and Writing Skills of the first-year students at the Faculty of Commerce.

\section{Main findings:}

The current study reached the following results:

1- The proposed program has positive effect on developing students' reading comprehension skills.

2- There is a statically significant difference at (0.05) level between the mean scores of the students on the pre- post administration of the reading comprehension test in favor of post -test.

3- Foreign language instruction supposes that leaner-centereness is an important element and reacting to learners' wants and interests in the teaching and learning process.

4- For students' future career in the field of Business, it is essential to read authentic materials to 
develop reading comprehension skills for commerce students.

\section{Recommendation:}

Based on the results, the following recommendations are provided:

1- Needs analysis should be taken to consideration by the curricula designer before designing an ESP program because it helps the teacher to identify students' needs.

2- Cooperating of ESP professionals with subject specialists to make the teacher feel confident and to design an ESP course including commercial terms that are useful for students' future career.

3- Integrating E-learning and online courses into learning process to improve different skills of undergraduate students.

\section{Suggestions for Further Research:}

The following suggestions are offered:

1. The effect of using other ESP online courses should be employed to develop other language skills such as listening and speaking.

2. The effect of applying Elearning should be employed on different courses within different disciplines that university students study.

\section{Conclusion}

The findings of this study open new horizons for ESP curriculum design for developing specific English courses that cater more for the need of the learners. Improving reading comprehension skills in English for Specific Purposes encourage and enable learners to understand the content of the text. Results of this study show the program's effectiveness in improving students' ESP reading comprehension skills.

\section{Reference}

ARNÓ-MACIÀ, E. L. I. S. A. B. E. T. (2012). The role of technology in teaching languages for specific purposes courses. The Modern Language Journal, 96, 89-104.

Marco, M. J. L. (2002). Internet Content-Based Activities for English for Specific Purposes. In Forum (Vol. 40, No. 3, pp. 20-25). http://exchanges. state. gov/forum/.

Omar, M. A. (2015). Improving reading comprehension by using computer-based concept maps: A case study of ESP students at Umm-Alqura University. British Journal of Education, 3(4), 1-20.

Elsheikh, A. A. E. (1987). GENERAL AND SPECIFIC ENGLISH LANGUAGE SKILLS IN RELATION TO ACADEMIC ACHIEVEMENT.

Celce-Murcia, Marianne. (1991). Teaching English as a second or foreign language. Massachusetts: Heinle \& Heinle publishers.

Urquart, A., \& Weir, J. C. (1998). Reading in a Second Language: process and product. Practice. 
Chai,H (2001) Reading Activities for Effective to-down processing English teaching forum. 39 (1), 22-55

Egbert, J. L., \& Petrie, G. M. (Eds.). (2006). CALL research perspectives. Routledge.

Harmer, J. (2001). The practice of English language teaching. London/New York, 401-405.

Carrell, P. L. (1998). Can reading strategies be successfully taught.

Afflerbach, P., Pearson, P. D., \& Paris, S. (2008). Skills and strategies: Their differences, their relationship, and why it matters. Reading strategies of first-and second-language learners, 11-24.

Snow, C. E., \& Sweet, A. P. (2003). Reading for comprehension. Rethinking reading comprehension, 1-11.

Day, J., \& Krzanowski, M. (2011). Teaching English for specific purposes:

An introduction. Cambridge, United Kingdom: Cambridge University Press

Golonka, E. M., Bowles, A. R., Frank, V. M., Richardson, D. L., \& Freynik, S. (2014). Technologies for foreign language learning: a review of technology types and their effectiveness. Computer assisted language learning, 27(1), 70-105.
Salama,N.(2016) The Effectiveness of Electronic Program based on ESP to develop Home Economics Student's Oral Communication Skills. Unpublished Master's thesis. Damietta Faculty of Education

Pritchard, R. M., \& Nasr, A. (2004). Improving reading performance among Egyptian engineering students: principles and practice. English for Specific Purposes, 23(4), 425-445.

Bitchener, J., \& Basturkmen, H. (2006). Perceptions of the difficulties of postgraduate L2 thesis students writing the discussion section. Journal of English for Academic Purposes, 5(1), 4-18.

BOUKLIKHA, W. G. (2016). Practice of the Reading Skill in an ESP Context Using Web-retrieved Materials: The Case of Engineering Students at the University of Tlemcen (Doctoral dissertation).

Marshall, S., \& Gilmour, M. (1993). Lexical knowledge and reading comprehension in Papua New Guinea. English for Specific Purposes, 12(1), 69-81.

Torregrosa Benavent, G., \& SánchezReyes Peñamaría, S. (2011). Use of authentic materials in the ESP classroom.

Celce-Murcia, Marianne. (1991). Teaching English as a second or foreign language. Massachusetts: Heinle \& Heinle publishers. 
Johnson, K., \& Johnson, H. (Eds.). (1998). Encyclopedic dictionary of applied linguistics. Blackwell Publishing.

Bruce, I. (2011). Theory and concepts of English for academic purposes. Palgrave Macmillan

Hutchinson, T., \& Waters, A. (1987). English for specific purposes. Cambridge University Press.

Harmer, J. (2001). The practice of English language teaching. London/New York, 401-405

Grabe, W. (2004). Research on teaching reading. Annual review of applied linguistics, 24, 4469.2003)

Sweet, A. P., \& Snow, C. E. (2003). Rethinking Reading Comprehension. Solving Problems in the Teaching of Literacy. Guilford Publications, Inc., Dept. 3R, 72 Spring St., New York, NY 10012.

Day, J., \& Krzanowski, M. (2011). Teaching English for specific purposes:

An

introduction. Cambridge,

United Kingdom: Cambridge University Press

Swales, J. (1992). Language for Specific Purposes. In W. Bright (Ed.), International encyclopedia of linguistics (Vol. 2). New York, Oxford: Oxford University Press, p. 3

Kharma, N. N., \& Hajjaj, A. H. (1989). Use of the mother tongue in the ESL classroom. IRAL: International Review of Applied Linguistics in Language Teaching, 27(3), 223.

Dictionary, M. (2014). Web Browser. printed Nov, 12, 10161.

Tsai, S. H. E. (2006, March). Integrating WebQuest learning into EFL instruction. In Society for Information Technology \& Teacher Education International Conference (pp. 2061-2067). Association for the Advancement of Computing in Education (AACE). 